\title{
An Interview with William Stafford
}

\section{Cynthia Lofsness}

INT: Do you read much contemporary poetry?

W.S: I do read a lot of contemporary poetry, but it's sort of like nibbling olives or something.

INT: Which contemporary poets do you feel some sort of affinity with?

W.S: I like Thomas Hardy and feel much more affinity with him than with any contemporary poet I can think of now . . . of course he was almost contemporary . . . . he died in the late 1920's. I understand Thomas Hardy by sympathy. . . . To many he seems kind of pessimistic, but I get a kind of feeling of elation out of Hardy ... you know, if human beings inhabit that kind of world it's not their fault. And besides, I just follow his sort of totemistic or feeling of natural influences way of living.

INT: You said you liked Hardy "by sympathy". I recall reading somewhere that you said you liked Yeats, but had no sympathy for him.

W.S: Yes, that's true. Yeats seems foreign to me. . . I'm excited by a lot of those violent encounters of images and so on, that he cultivated in his mind, but that kind of recklessness with images for the sake of firework displays in poetry is just foreign to my nature. It's like visiting a quaint and odd person ... but when I read Hardy's poems, I keep having that "huh-huh, yes" feeling. The "I understand" feeling.

INT: When did you first realize that you wanted to become a poet?

W.S: I've thought about that, and sort of reversed it. My question is "when did other people give up the idea of being a poet?" You know, when we are kids we make up things, we write, and for me the puzzle is not that some people are still writing, the real question is why did the other people stop?

INT: Do you think that getting to know a man through his poems is possible?

W.S: It seems to me that poems, and other kinds of art works, are disguises. I don't mean deliberate disguises, but they are created by following out hunches that are not at all ones that are necessarily central feelings, or durable commitments, but just opportunities. At least when I write, I feel like the kind of person who is ready to try all sorts of things.

INT: So you think then that even reading a great deal of a writer may not bring us close to him as a man?

W.S: Yes, what we learn is what they've written; but what they are is what they haven't yet written. What they are is sort of why they wrote it. A poem is not a direct revealing of a person. . . . In my way of writing I've compared it to Daniel Boone going over into Kentucky and finding things . . . Daniel Boone is not Kentucky ... 
INT: You once said "The influence I feel when I write, the voice I hear most clearly is that of my mother. . . . I don't really hear the voice of T.S. Eliot very much." Could you comment on that further?

W.S: Yes . . . it was part of my general thesis that a writer is really working by means of those things that are closest to him, his sustained immediate feelings .... and it's just part of my feeling, and it's also just a statement of what I feel to be the truth . . . that when I notice little turns of speech, and attitudes towards events and people, I sense the presence of my mother's nature and her way of talking and a certain kind of not very assertive, but nevertheless, tenaciously, noncommittal judgmental element that was in her. Not to assert very much, but on the other hand, to assert what she felt.

INT: What attitude of hers do you think influenced you most?

W.S: I think it was an attitude of not being impressed by the sort of stance or posture that most people take. I also remember her listening without making an overt comment, but nevertheless having her judgment about some person or some event. Later she would speak freely about it in a context where it wouldn't hurt the other person.

INT: You mentioned that you didn't hear the voice of T.S. Eliot very much; would you please comment upon two quotes of his from the essay "Tradition and the Individual Talent?"

W.S: Yes, I know that essay.

INT: He said, "The progress of an artist is a continual self-sacrifice, a continual extinction of personality. Poetry is not the expression of personality, but an escape from personality." Would you comment upon that?

W.S: (slight laughter) I have kind of a complex reaction to that. I can't feel the separation between the artist and the person in the immediacy of his experience. For me, writing (maybe other art, but I'll stick to writing for this) is a process of relying on immediate pervasive feelings, not an escape from them at all, not at all. . . . However once you enter into what the material is offering to you, you begin to build up something and your creation may seem to others like a disguise or something different, but for me it's like thinking. When I think, I think all sorts of things . . . half of my thoughts are the other extreme from what I finally commit myself to . . . so the poem may be wildly various, but I'm relying on little impulses that seem to me very close, exactly congruent to the self that I use in other negotiations.

INT: How do you feel about the poets writing now?

W.S: Of the men writing now, I think the best is . . the most significant American poet now is Robert Lowell by quite a distance, I think, and I admire or am impressed by, would be more like it, the involvement with his material . . . it comes right out of a believable complex or tangle of feelings and background, so I would rate him the highest. There are quite a number of current poets I feel congenial about. . . . I like Galway Kinnell. . . . I think I understand him by sympathy. . . . I feel excitement about and a kind of willing participation when I read quite a number of current poets, 
but I don't think there's a one who is fully sympatico. I don't know how to get at this. . . . They are doing it with their minds or something and Thomas Hardy was doing it with some kind of instinct, and that interests me more.

INT: Would you compare Roethke and Lowell?

W.S: There are some things that Roethke did that are very extreme, and in a sense unsurpassed, in the sense that no one else has gone that far beyond certain boundaries. His way of writing, his little sort of lizard flashes into unknown territory are intriguing; but they don't have the kind of cumulative effect or the pervasive involvement with current life that I feel in Lowell's work.

INT: Do you feel that the arts have been dominated by men?

W.S: I do feel that the arts have been dominated by men, and I do feel that many injustices have just grown up and been perpetuated . . . through the operation of influences in society that I don't fully understand. But I feel now, and I've felt for a long time that there are many injustices, and I suppose that's obvious in the ratio of the relative number of men and women in the arts, and in other endeavors too, is pretty largely a function of this endemic discrimination that's been going on. But I have myself, admiration for many women writers.

INT: Do you think there has ever been a major American woman poet?

W.S: Yes, I think Emily Dickinson is a major American poet. Period.

INT: And the best woman poet writing today in your opinion?

W.S: Uhmmmmm . . . American?

INT: Or English.

W.S: (laughter) . . I I was looking for some help . . . to figure out . . you know . . . let my mind range more.

INT: Perhaps if I rephrased that. Do you think any woman writing today shows signs of greatness ... or the possibility of becoming a major American poet of the stature of say, Emily Dickinson?

W.S: I don't think there is any poet writing today, man or woman, who is as great as Emily Dickinson.

INT: Not even Robert Lowell?

W.S: (laughter) Yes, not even Robert Lowell. But, of course, Emily Dickinsons don't happen very often. And as for American women novelists, I have an immediate allegiance for someone like Willa Cather ... I think she is a great writer ... her novels are solid, and great. And when I read back in English literature to the 19th century, I have great admiration for George Eliot, for instance, I think that she is, that her novels are, first rate, and of course, Jane Austen too. In a way, I seem to be avoiding the current scene, which I don't want to do; it's just that there are a number of women poets, I think, today who are right in there with men poets, it's just that the whole literary scene is too near and blurred for me to separate them out the way I separate out Thomas Hardy and Emily Dickinson . . . to them I give my allegiance. 
INT: You mentioned Willa Cather ... she wrote about the area in which you grew up didn't she?

W.S: Yes ... the plains ... but she also wrote about Mexico and Canada.

INT: Did you read her when you were quite young?

W.S: Yes, I did . . . and my mother read her . . . come to think of it . . . my mother's taste in stories in general and in novels is very much like my own ... and she'd read books over and over again, and I sort of understand that...

INT: Do you read books again and again?

W.S: Yes, yes.

INT: Which ones?

W.S: Well, I probably know a lot of Huckleberry Finn by heart, which I like, and I've read Dickens, and I read people like Walter Scott with a great deal of gusto. People today think it doesn't go fast enough, but I think it goes too fast (laughter), I like to relish those slow, expansive, luxurious novels.

INT: In a late poem, "Let Them Alone," Robinson Jeffers says speaking of poets "Let him alone. . . . He can shake off his enemies but not his friends." Would you comment on that?

W.S: I don't feel the menace ... I don't feel that my friends are a menace . . . but on the other hand, I'm not a poet like Robinson Jeffers. I think I understand why he says this, and it does seem to me that many writers, artists, and intellectuals, of all kinds, are victims of people around them, but of course it's a mutual thing. I mean they're willing victims, that's why they're victims. I mean victims in the sense that they get to needing immediate reactions from human beings . . . they get to feeling lonely, and they keep wanting to check what they're doing with all their friends, and that doesn't seem to me to be a good thing to do. I would like to be like the person who raises vegetables. . . . I don't have to run out and show someone passing in the street how good my onions are . . . they're just growing, that's all ... nothing especially remarkable.

INT: What if you take Jeffers' statement in light of say grants and fellowships, and awards; do you think they can have, besides the beneficial aspects, any detrimental results?

W.S: I think they could have detrimental results . . . almost any good thing could, but grants could, if a person begins to organize his life so as to sustain his ability to get grants, then that's one kind of distraction from the pure following out of what he's doing. So I think it's a little bit better to have some kind of a job, some kind of check that you count on, some kind of vocation that won't engulf all of your life. But, I keep telling myself that a grant, now and then, is not too corrupting.

INT: The question that I probably can't phrase as well as I'd like to concerns the commitments you mentioned awhile back . . commitments, as I see them, to the human family, to civilization. Whether one calls it commitments or appropriately the title of your new book Allegiances, it's prob- 
ably as strong or stronger in your work as can be found in the work of any poet writing today. . . . At what time were you conscious that that was the fork in the road that you took?

W.S: Well, I'm not sure I've been conscious of that as a commitment . . . to me it's more like ... the book doesn't say commitments, it just says Allegiances, and this is more like something that comes naturally to a person ... it's like feeling at home in the world. . . . I do feel at home in the world ... it's like assuming good will on the part of other people . . . I tend to do that. It's like a kind of level look at every day's experience as it comes at you and welcoming it. I feel that . . . you know . . . not alienation, not resentment, or rebellion, but a kind of acceptance and even a hopeful acceptance that enjoys being part of the human family . . . something like that ...

INT: Your poem, "Traveling Through the Dark," seems to speak more of a commitment, however. Especially the line "I think hard for us all."

W.S: Yes. You know that is not a poem that is written to support a position that I have chosen, it's just a poem that grows out of the plight I am in as a human being.

INT: But it is definitely to people as versus animals and the world of nature, that your allegiances lie.

W.S: I can't help feeling a little bit closer to people than to animals.

INT: Have you ever felt in agreement with Whitman in his "Song of Myself" when he states that he feels as though he could turn and live with the animals, they are so placid and self-contained . . . not a one of them gripes....

W.S: They're not whimpering and so on . . . Yes, of course I've felt that but that's just a part of myself that springs out of some temporary feeling of pique or perception or human encounter . . . I would have that feeling in an extreme of thinking, but I wouldn't have it as a set policy . . . mostly I'd rather live with people.

INT: What causes or gives rise to this pique ... what disappoints you most often in other people?

W.S: Well, I find myself stumbling into human situations that are like traps already set, you know. . . . Maybe people's resentments are built up by conditions that I haven't anticipated, so I don't always meet that good will and welcome into the family kind of feeling . . . that is upsetting to me ... . and if $I$ have a principle about it, it is well remembered this came about through circumstances that you didn't anticipate . . . your job is not necessarily resentment, but understanding and hope for better luck next time ... something like that.

INT: You once mentioned that you like the work of Robinson Jeffers very much ... and yet so many of his ideas are almost polar opposites of yours.

W.S: When I read Robinson Jeffers I have a steady sense of where he is . . . sort of like where the north star is, or anything that's pretty far off, but definite. And his poems express often what many people feel is a violence, pessimism, and so forth, yet they spring from a point of view which for 
me is very steady and understandable. After all, those extreme statements come from some kind of commitment and involvement on his part. I mean . . . it's sort of like Jonathan Swift . . . if he didn't care, he wouldn't write that way. . . . He cares. . . I understand.

INT: What do you see as the main advantages of working as a college teacher?

W.S: I like the academic world, myself. I think that many people outside it have forgotten or have never fully realized the great advantages in the academic world. You meet people in your daily life who are committed to a way of proceeding that I find very congenial . . . that is, they are looking for help in revising tentative conclusions . . . they are not doctrines and policies that are deciding once and for all .... it's kind of an adventurous search among like-minded people and to me this is very important. Out in the world, in the world outside, you keep meeting people who are like robots, they are committed to something they're programmed for their life work . . . but in the academic world, our life work is a steady process of findings, discoveries, readiness. . . I think it's a great place.

INT: What disadvantages do you see in the academic world?

W.S: Well the academic world is always changing . . . that is the people you meet are always changing. . . . For me one of the trials is that I'm surrounded by people I don't know well enough to have a close relationship with . . . I'm thinking about the student generations who pass by so fast ... on the other hand, there are a lot of them . . . so in a way, your contacts with people are all diluted and changed all the time . . and my instincts or my nature is for steadier, fewer people. I'd rather either not know someone at all or know them very well. . . . You know that's easy . . . but in the academic life it's always that sort of in between.

INT: What do your learn from your students?

W.S: For me the students are not a special group . . . I mean they are an intelligent pretty lucky kind of people usually ... college students are a pretty lucky group, in general, and so it's fun to know them, but I don't quite share the opinion that some people have that every student generation seems to be a whole lot better than the one before in all sorts of ways . . . I have reservations about that. . . . I think what we learn from each other is that we are all somewhat fallible . . . I learn particular things from students . . . you can always learn particulars from different people, so I don't class them as a group . . . they're just too transient to be of the greatest value, but they are a great potential.

INT: What are your goals as a teacher?

W.S: Well, I just sort of stumbled into teaching . . . and my goals in teaching are more of an incidental thing. ... I have an interest in literature and writing, so I'm hired to be on a campus where some others may have that convergent interest, and our interest is not so much in each other, as it is in literature and writing ... it seems to me, or at least this is the stance I take.

INT: You mentioned that you just sort of stumbled into teaching, what had you done prior to teaching? 
W.S: I tried many things . . . I worked as a laborer, I worked for the forest service, which I liked . . . I worked one year as a kind of secretary and man of all work in the office of a church relief organization, Church World Service, and I liked that year. . . . There are a lot of things I haven't done, but that I'm thinking of doing. . . . I like the idea of photography, or farming. . . . I would like to have some kind of skill that would make it easy for me to know when I have finished a job . . . one of the maddening things about the academic life is that you never know when you've done the job ... there is no feeling of closure, and I like to be able to let it go click.

INT: In the anthology, Naked Poetry, you included a small article that contained the statement, "the feel of composition is more important than any rule or prescribed form."

W.S: Yes, yes.

INT: This seems to say to me then, that emphasis placed on technique is wrong, so I wonder then what is your opinion of writers' workshops, or the poetry workshops and other type apprentice-type programs?

W.S: Well, I have to say something that will probably seem contradictory and I don't know what to do about it, except just be honest. That is, I've liked writers' workshops, I've served easy time . . . many schools and many jobs like them. If something is pleasant and seems to be productive, I can't help feeling that it's all right, that it's doing some good. On the other hand, I continue to be puzzled by what people mean by technique. . . . I just can't come at it that way. I just don't know what they mean . . each poem seems to me to be a new kind of plunge.

INT: I would define technique as a belief on the part of the poet that there are certain rules or forms into which his ideas must be channeled for proper expression. A belief that there is a proper "framework," into which he must fit his specific feelings ...

W.S: Then I see why I don't understand technique. When I'm writing, I'm not at all trying to fit in any forms, though I think it's easy to do, by the way, that doesn't seem to me the crucial or essential thing, and I suppose this feeling is the source of that quote about the feel of composition ... . it's not a technique, it's a kind of stance to take towards experience, or an attitude to take towards immediacy feelings and thoughts while you're writing. That seems important to me, but technique is something I believe I would like to avoid.

INT: What then is your opinion of the Black Mountain school of poetry with their breathed lines ... so many breaths per line etc.

W.S: I read, reviewed in fact, Charles Olson's Selected Writings, with an introduction by Creeley a few years ago, and when I had the assignment to review this book, I thought, now's my chance to learn what this is all about. You know, I had been hearing about it all my life and sort of giving a general assent, not being negative, so I read it carefully, and I thought that many of the positions taken about writing, about poetry, lines, and so on, seemed quite congenial to me ... it didn't seem like news ... it 
seemed like, yeah, that's what I thought everyone thought.

INT: Do you think it has produced good poets . . . would you consider Creeley, and Olson and Wieners to be good poets?

W.S: I think Creeley is a good poet. I can't feel at all persuaded by Olson as a poet. . . . I just don't feel engaged at all . . . it's like a passing of each other in the corridors on different levels, or something, and so for the others. But Creeley I do understand. I can't help feeling that there are more differences among those people than they're syndicating themselves together would lead one to believe. It seems to me, that they are separate writers who happen to have a label.

INT: What do you think of Robert Frost? Why do you think he was singled out to be THE American poet?

W.S: Well, I can't help thinking that part of Frost's centrality in American life comes from qualities that are not necessarily good, or not necessarily important for poetry. He lived a long time, he showed up well in photographs, and you know, he came from the right part of the country. . . . His reputation just followed the tide of the pioneers and so on. (pause)

INT: What about his reputation as the wise old New Englander, and the Backwoods Prophet?

W.S: (in a sharp tone) I don't feel he was wise at all, his political advice seemed to me poisonous, and his influence on politics if he had any, just seems to me feedback of stereotypes. So I don't consider him a seer at all or wise man or prophet or anything like that. But he was a tenacious old guy who wrote some interesting poems.

INT: I would be interested in knowing if you feel you have any flaws as a writer, either conspicuous ones or secret ones?

W.S: Yes I think I have many flaws as a writer. . . I I usually try not to brood about these things, because it doesn't do much good. On the other hand, it might be good to think about it now and then. One of them is just limitations ... just not being fast enough . . . or ranging enough in thought, just not being rich enough intellectually. ...

INT: You write a lot. ...

W.S: Well, yes, I see what you mean . . . yeah, yeah . . . of course, anyone though, can write a lot . . . but is what you write a product of real flashes of realization? of imagination and so on? I feel that certainly I am heavily burdened with limits. What I think of . . . I don't think of enough! and I don't perceive relations between things vividly enough, coherently enough, cumulatively enough. So most of the flaws I think of if I stop and ask myself . . . I don't feel any stabs of lost opportunity it's not that at all.

INT: Do you have any regrets about your writing or your career?

W.S: Well I don't have regrets in the sense of thinking . . . if only I had done so and so, I'd be a major poet, or something like that. No, I don't think I could have managed it any better . . . you see what I mean. Alas . . I can't blame any particular mistakes, it's just kind of a steady limitedness. That's what I feel.

INT: If you were to be remembered by only one poem or say, if only one poem 
of yours could survive for future generations, which one would you select?

W.S: I'm not sure I can figure this out, but I do have an immediate impulse of the kind of poem that immediately occurred to me would be some little little sort of nagging thing that no one would think very much of at any certain time, but they would never quite get rid of . . . it would just be there. And I think of a poem of mine that's not necessarily at all the poem, but at the end it's a poem about dandelions on the church lawn. ... I forget how it goes, but at any rate the very last line . . . these dandelions go floating away, and they are saying their little song: "God is not big, He is right." (laughter)

INT: Do you find any pattern of ideas recurring in your work?

W.S: Well one of the elements is not a pattern of ideas, but a feeling of coziness or a feeling of being at home. It's like the delight of having shelter in a storm or it's like the feeling of becoming oriented where you've been temporarily disoriented . . . or something like that. I would expect to find that showing up in the patterns because that is what I like to think I like to find.

INT: Your father is so frequently present in many of your poems . . . I wondered if you would tell me a little about him ... how he influenced you and your feelings towards him?

W.S: Well, I feel very positive in favor of my father. I've talked to quite a number of writers who have felt rebellion. My father was always very sympathetic and helpful and sort of a level equitable person throughout my life, steady with counsel, but not intruding. All my life long I've had a feeling of ... not of rebellion, because there was no oppression . . . there was a kind of interest and even surprise and delight, but no oppression at all. I feel very positively about him and I suppose it shows up in the poetry.

INT: What do you think your father would have thought of Allegiances?

W.S: You mean the new book?

INT: Yes.

W.S: I think he would have liked it . . . and I think he would have liked it for a reason that is inherent in the book and in my own feeling about it, I believe, and that is he would never have assumed that any one separate poem is the total statement of a person, you know, they are try-outs, he tried things . . . he would write things, read things, talk easily . . . even recklessly, and assume good will on the part of the hearer and the other speakers ... a and I believe the book is like that.

INT: Did he also write poetry?

W.S: He's been known ... he did a little bit of that and he tried various things ... and he always had an interest in what other people tried in that regard.

INT: Have you done any translating?

W.S: Yes . . . I tried some Spanish, which I know, a little bit, I took it in school ... . and I've tried translating some French, which I had to learn to read, sort of, and I've recently been engaged in translating from the Urdu. Do you know about the Urdu? 
INT: Galib?

W.S: Yes the Gazhals of Galib, and this was just because. . . I I mean all those translations came about just because people suggested to me that I try it, and somebody else helps, and gives the first version, and I try to make an English poem out of it.

INT: You have translated from the Spanish poets . . . would you include any of the great Spanish poets among those you greatly admire . . . men such as Neruda, Lorca, Vallejo, etc?

W.S: Even though I tried to translate those people, and had some of the translations published, I can't feel that I know their poems well enough to have very much judgment about how I feel about them. All I know is that some of the prose bringings over into English were interesting enough to be occasions for interesting projects for me to write. But I don't know them well enough to judge them, so I couldn't include them.

INT: Would you please compare the creative powers involved in writing your own poems and those involved in translating?

W.S: I always feel reluctant about going into translations . . . it's like doing a job whereas writing poems is more like fishing, you know, a sport. Strangely, I feel more secure about doing translations, because I know I'm going to come out with something; but I don't feel a sense of adventure and that's a distraction.

INT: Would you tell me something about your work habits?

W.S: Yes, I get up early in the morning, before anyone else, so that there is a space of time that won't be interrupted . . . it's quiet, I'm wide awake, and then I just start to write whatever occurs to me, no matter how trivial, in order to get into motion, and the process of writing calls up other things, and a kind of train sets in, the sequence that comes about because I'm in motion. And every morning there is something to write about because it doesn't have to be much. It can be anything, there's always something.

INT: Every morning? Are there mornings when you can't write?

W.S: There are never mornings when I can't write. I think there are never mornings that anybody "can't write." I think that anybody could write if he would have standards as low as mine. (strange laughter

INT: What about revisions, and reworking your poems . . . do you tend to work on several poems at once, do you wait until one is finished, do you start at the beginning and keep rewriting etc?

W.S: I don't have any feeling about refraining from working on several at once ... I mean if I'm enticed by something, I may write something different tomorrow from what I'm writing today, and so, there may be two or three things going and maybe none of them ever get finished, but maybe all of them might. . . . So I think maybe three or four . . . it just depends upon how much distraction one individual can stand. So I have all sorts of things just moving along, maybe, and I do revise in the sense I do go back over what I write, but it doesn't seem like a different process . . . it's just the same process, going back through the same terrain again .. seeing if the 
signals are different, and then seeing if the signals are different the next time. And every now and then, you may get a little nudge of a new idea, or adjustment, and you do it, and that makes it easier the next time. And finally when you run out of profitable moves, or when you are enticed away from it, then it's done. If it's done.

INT: In your lecture, you referred to abandoning poems.

W.S: Yes . . . I was remembering an Auden quote I heard that "poems are not finished, they're just abandoned." And I do understand this, because I don't know when a work is finished . . . it's always subject to revision.

INT: Have you ever gone back and worked on a poem that you once considered finished?

W.S: No because after they are so old . . . maybe six or seven days old, they for some reason, they always just seem to have been written by somebody else. I'm more interested in something newer than that. So I've never gone back to do extensive revisions of old work.

INT: Today when there seems to be almost more literary criticism published than literature, I would be interested in your opinion of the critics who feel they can approach the "man behind the work" through his work. Do you think this is a valid assumption?

W.S: I don't think they can ever get there. For me, the difficulty of the critic, the incapacity to ever get there is no reflection at all upon the individual critic or anything like that. It's just that the process of writing is a kind of weaving forward from one thing to another, and to go back through that process of writing and try to unravel it, being another person with another sensibility, and different sets of experiences. . . . You can see the hazards that multiply.

INT: You mentioned in an interview back in 1962 that you felt alien as a poet from the rest of the community. Do you feel this way now?

W.S: No, not so much. I did feel removed, because to me, at that time, it seemed odd to take time to write and since then, I found that the community forgives more than I thought. . . . That is, I have learned that there are lots of other people doing things that are not so ordinary, and, I think that was part of my provinciality about the complexities of society.

INT: Why did you wait so long to publish your first book?

W.S: Yes! People said you know, you waited until you were into your thirties, or something like that, but I wasn't waiting! I just didn't have a publisher! I kept sending out poems, and . . . I don't know how to feel when someone talks to me about waiting, because it certainly wasn't any policy on my part, but on the other hand, I don't feel that anyone was slighting me . . . it's just that I had the poems there, and maybe I didn't always send them to the right place, it just didn't happen, that's all.

INT: In 1962, you characterized yourself as "one of the quiet of the land, even somewhat conservative." Would you describe yourself that way today?

W.S: Well, I think that holds up better than some of the things that I said in that interview. Yes, at least as conservative as possible . . . you know, I don't like the idea of going around looking for opportunities to disagree, 
and so I feel like a person who would like to conform so far as possible . . . you know of course there are limits, and so I would like to reduce the attempt to be rebellious without reducing the willingness to take meaningful stands on essential things. Something like that.

INT: You did take a meaningful stand by refusing to serve in World War II.

W.S: Yes, yes, there are some things that one should just never do.

INT: What led you to make the decision to be a conscientious objector?

W.S: Well in World War II that position was an odder one than it is now ... And I suppose family background had some part in it and a kind of feeling of assuming good will on the part of other people, and being puzzled about how a line on a map kept people over there from being also people of good will. And my parents were always skeptical about general judgments around them ... they were reserved about accepting patterns of thought without a little juggling of their own. They were always reading foreign books. And I just could not come down to nationalistic location for virtue. So I was a conscientious objector.

INT: You also said that you believed "that people, in their best selves are social and mutually helpful, and that any other policy would be a kind of suicide." You continued that thought by saying that "a long term cold war, or a cold anything, is to foster among us a paralysis of those qualities on which we commonly and ultimately have to rely." That was 1962 . Instead of a cold war, we now have a genocidal war raging in Asia . . . what's to become of us ... any predictions etc.

W.S: Yes (sighing). Well, my impulse is to feel uncomfortable about that formulation, you know, it sounds more sure of things than I really am . . . although events seem to bear it out all too well. . . I I mean a long enduring kind of conflict has brought us to feeling suspicion among ourselves, and divisiveness, and it's very hard to maintain the sense of community that seems to me to be necessary for the health of the country or in a society when we are torn. And some of us sadly forced to be in munitions and actually in fighting and so on. So I don't feel that much of a prophet. . . . I suspect that was pretty much formulated by the person who did the interview because it's his position, but I can't disagree . . . it sounds a little more assured than I feel myself.

INT: In reviewing The Rescued Year, Louis Simpson stated that you were a "True Poet," and said that "if ever this country is going to have a sense of itself, it will be through work like Stafford's." What "sense of itself" would you like to give to the American people? What quality or qualities would you like them to recognize and/or come to terms with in themselves?

W.S: Well a judgment like this about poetry puts me in a strange spot because when I write I don't have any program, any idea of any purpose to tell the American people about themselves, or anything like that, or how they ought to be. But instead it's just like groping forward into an experience of my own . . . that is, here a critic has judged the product, and I feel flattered that he would notice the product and judge it so favorably. But I really didn't write it with the intention that is ascribed to me . . . so I don't 
know what to do. I think critics have often manifested the essentially random nature of critical remarks. It's hard to get parallel to the writer's way of working, so you keep crossing his poems and you say things that are true, but I think the writer keeps thinking, or at least I keep thinking, all right, all right, but then I think other things too. In general, I think poetry criticism, as written by poets, they do know the most about it, but they're also, most of them, too careful, too benevolent. I don't mean that they ought to be mean to each other, but we have to learn to accept the person's acceptance and rejection. A critic ought to be at least as mean as a poet. And most poets, when they turn critic, either turn entirely mean, except to their gang, or they get too soft.

INT: Quite honestly, I'm not trying to pester you, but if we could go back to Simpson's remark about this country hopefully having a sense of itself. Your poetry aside, what would you, William Stafford, like the American people to recognize about themselves?

W.S: I would like to see them recognize the complexities faced by other people. I would like them to have an increased sense of how issues bring about alienation between groups that are self-justifying . . . somehow, or to put it another way, I would like to try to help the American people to see the possibilities of reconciliation. I don't find myself in harmony with the current style of the politics of overcoming . . . I have a kind of feeling for empathy with others, including extremely different others.

INT: Do you believe the spirit of assuming good will on the part of others, and the other goals you just mentioned can be achieved in the present structure or framework we live in, in this country?

W.S: Not entirely, apparently, but somewhat, yes. For, the world is a somewhat place, and ah ... . little bonuses and benefits are very much to be desired. And in order to achieve the unattainable, we may destroy little pieces of the good life, and I believe we can increase the good life by treasuring the little pieces of it. This is a kind of Burkian position.

INT: The little things that make up the good life ... what are the little pieces of the good life for you? What brings you happiness?

W.S: I would like to be able to meet all kinds of people, including the enemy ... under conditions, I would like to maximize the conditions of meeting them so as to bring us to perceive our mutual interests, rather than to drive them farther away. It's a way of life that hasn't prevailed, it hasn't brought peace into the world, but we share that frustration with a lot of other people.

INT: Do you think that one man really has another man as his enemy? Do you think we can call other people enemies?

W.S: I'm reluctant to do that . . . instead, I would like to make that kind of reach I was talking about, that empathy, to understand.

INT: Stanley Moss, in reviewing The Rescued Year in the New Republic said that "Stafford is engaged in a battle for his soul . . . he is closer to Faust than to Job."

W.S: (chortling laughter, as if hearing it for the first time) Well, I do like that 
idea . . . and actually, in my own life, and in my writing, I do feel exhilaration of a kind of promise and partial fulfillment, at times a kind of a struggle . . . but I'm kind of surprised that someone would see it in the poems ... again, I read a critic, and I sort of like what he says, but I don't know whether it applies more to me than to somebody else . . . I suspect that it is something that the critic is doing. Usually what the critic identifies is something that he either wants to do, or doesn't want to do ... I mean he has some kind of orientation toward the topic himself, and he finds it in the poet, and since we all have many things in us, I'm not surprised to find myself agreeing, but not entirely agreeing.

INT: So you feel closer to Faust than to Job . . . what if I were to ask you to identify with one person from the Bible, whom would you pick?

W.S: Ohhh . . . I don't know if they have any of my class in the Bible . . . I really hadn't thought about this . . . if I had my druthers, I would like to be somewhat like Moses . . . but, that's not really my role. Ah . . . I really don't know.

INT: Well, in reading the Bible, are there any persons with whom you feel like exclaiming "Yes, me too!"

W.S: Different moods, different persons. I suppose sometimes I feel like those people driven out into the wilderness, you know. I never do feel a mystic, or like one who perceives the truth. I would feel more like some kind of wanderer, blunderer, but nevertheless, a benevolent wanderer or blunderer.

INT: In writing about your poem, "Fifteen," Stanley Moss made a rather unusual remark. He said that he "suddenly realized that someone like the bleeding motorcyclist crashes into almost all of Stafford's poems, and that motorcyclist is the poet himself."

W.S: (laughter) Oh ho ... I see ... Yes . . . suddenly I do remember other poems where people do come crashing in.

INT: He says that you are "deceptively simple."

W.S: (laughter) ... O Oh, I like that . . . I think it's true. I think he's right. I am deceptively simple . . . in other words, I'm not really simple. Okay, all right.

INT: You said the other day that if writing is continual, there is more of a chance of something happening ...

W.S: Yes . . . I've experienced that the activity of writing does make things happen. ... That's the way ideas come about for me ... through a willing acceptance of sub-ideas that aren't really dignified enough for most people to pay any attention to, but if I begin to pay attention things always come. ... It's not writing from a reservoir; it's like engaging in an activity out of which things come.

INT: What question didn't I ask that you would like to include?

W.S: Well for one thing, I would like to disassociate myself from taking any kind of stance that would imply that being a writer is assuming a power of guidance or insight or anything like that. I'm not that kind of writer. It seems to me a writer is engaged in adventuring into the language and all sorts of things occur to him or should occur to him, that's his job; the 
judging of these things, the selection of these things, and conduct in light of these things, is everybody's job. And I don't believe in discipleship or even leadership, or anything like that. Maybe this is one of the things I get from my parents . . . a kind of readiness, even when I was very small, for them to accept some things I could see that they couldn't see, and for me to accept some things they could see that I couldn't see. There was an easy give and take. I remember when I was a little kid, my father took me out for a hike in the country and we were looking for a hawk that we thought had landed in a line of cottonwood trees ... a and he said, "Now Billy, look carefully, in these trees-you may be able to see the hawk better than I can." For me, this is just a little emblem in my life . . . because I remember the jolt I felt: could I see the hawk before my father would? And his tone of voice just said, "Maybe you can, maybe you can't . . . give it a try."

\section{THE WHOLE STORY}

1.

When we shuddered and took into ourselves

the cost of the way we had lived

I was a victim, touched by the blast.

Death! I have death in me!

No one will take me in from the cold.

Now among leaves I approach, and I

am afraid that pain and anger

have crept their fire into my bones,

but the slaver around my mouth is drying.

I hope that the light on the hills can

pass open woods and slide

easily around slopes, hold my eyes

before they search their way to an enemy:

I have to contain all this anger, but with luck

it can pass directly into the sky.

2.

I am the sky. After everything ends

and even while the story goes on

I accept all that is left over. When all

the signals finally die, they still find

their way everywhere, meaning the same

as ever: they can't get away. I hold

them for something that approaches through winter.

3.

Though I am winter, through the light on the hills

I let children approach. In a pale straw slant

the sun angles down. Maybe the children will not see 